\title{
THREE NEW LICHENICOLOUS FUNGI RECORDS FOR TURKEY AND ASIA
}

\author{
K. YAZICI ${ }^{1}$ and A. Aslan ${ }^{2}$ \\ ${ }^{1}$ Biology Department, Faculty of Science, Karadeniz Technical University, 61080, Trabzon, \\ Turkey; E-mail:kcagri_1997@yahoo.com \\ ${ }^{2}$ Faculty of Pharmacy, Yüzüncü Yıl University, 65080 Campus, Van, Turkey
}

(Received 8 August, 2018; Accepted 9 January, 2019)

Three lichenicolous fungi, Abrothallus peyritschii, Lichenochora verrucicola and Sclerococcum montagnei, collected from Burdur and Bitlis provinces, are reported as new to Turkey, the latter species is also new to Asia. Short descriptions, including geographical distributions, hosts and comparisons with similar taxa are provided.

Key words: Ascomycota, biodiversity, Bitlis, Burdur, lichenicolous fungi, Turkey

\section{INTRODUCTION}

Lichenicolous fungi, growing as obligate parasites or saprotrophs on lichens, include a large group of about 1,800 taxa (Lawrey and Diederich 2018). They mainly belong to the Ascomycota (about 95\%), and the rest to the Basidiomycota (Lawrey and Diederich 2003).

Within our projects "Lichen flora of Muş and Bitlis Provinces" and "Lichen and bryophyte flora of Burdur province" we found some interesting lichenicolous fungi. No lichenicolous fungi had been reported previously from Bitlis province but from Burdur (Kocakaya et al. 2016). Although studies on lichenicolous fungi flora of Turkey have been increasing in the last five years, there are still many unexplored parts of Turkey (Yazici and Etayo 2014, Yazici et al. 2011). Approximately 146 taxa of lichenicolous fungi are known from other regions of Turkey (John and Türk 2017).

This number is still low when compared with other European countries or regions, e.g. Czech Republic (226 species including lichenicolous lichens, Kocourková 2009), Fennoscandia (430 species, Santesson et al. 2004), Germany (449 species, Brackel 2015a), Italy (525 species, Brackel 2015b). Great Britain and Ireland (403 species including lichenicolous lichens, Hawksworth 2003), Poland (216 species, Czyżewska and Kukwa 2009) or Ukraine (220 species, Darmostuk and Khodosovtsev 2017). Thus extensive explorations are urgently needed for more regions of Turkey.

According to the latest circumscriptions of the genera Abrothallus is composed of approx. 40 taxa (Suija 2006, Suija et al. 2015, Brackel 2015a, b), Licheno- 
chora 41 taxa (Lawrey and Diederich 2018), while Sclerococcum 13 sporodochial anamorphic taxa (Lawrey and Diederich 2018). Five taxa of Abrothallus, one taxon of Sclerococcum and two taxa of Lichenochora have been reported so far from Turkey (John and Türk 2017).

The present contribution resulted records from fieldworks in the region of Bitlis (eastern Turkey) and Burdur (western Turkey). The study area (Bitlis) has a climate characterised by very cold and snowy winters, and short, hot and dry summers, with mean annual temperature is $9.7^{\circ} \mathrm{C}$ and, with a temperature range from $-21.3{ }^{\circ} \mathrm{C}$ to $37{ }^{\circ} \mathrm{C}$, a mean annual rainfall of 822.9 $\mathrm{mm}$, and mean annual humidity of $61 \%$ (Akman 1999). On the other hand, in Burdur the climate is characterised by cold, snowy winters and very hot, long and dry summers. The temperatures range from $-16^{\circ} \mathrm{C}$ to $39^{\circ} \mathrm{C}$, while the mean annual temperature is $15^{\circ} \mathrm{C}$. The mean annual rainfall is $468 \mathrm{~mm}$ with an average humidity of $51.2 \%$ (Akman 1999).

\title{
MATERIALS AND METHODS
}

The present study is based on specimens from the Bitlis and Burdur regions collected in 29.06.2012, 17.07.2016 and 06.08.2016. Microscopical examination of hand-made sections was performed in water (incl. all measurements), $10 \% \mathrm{KOH}$, and lactophenol cotton blue. Air dried samples were observed and studied with a Nikon Zeiss Stemi 2000-c stereomicroscope and a Zeiss Axio Imager.A2 light microscope. Macrophotographs and microphotographs were taken with the digital camera Zeiss AxioCam ERc5s. The nomenclature of genera and species concept were followed according to Diederich (2015), Etayo and Calatayud (1998), Lindsay (1857), Nash et al. (2001), Navarro-Rosinés et al. (1998), and Suija (2006). Specimens are deposited in the herbarium of the Biology Department, Faculty of Science, Karadeniz Technical University, Trabzon, Turkey (KTUB). The descriptions are based on Turkish specimens.

\section{RESULTS AND DISCUSSION}

\author{
Abrothallus peyritschii (Stein) Kotte, \\ Centralbl. Bakt. Parasitkde, Abt. II 24: 76 (1909)
}

(Figs 1a-c)

Ascomata apothecia, with golden pruina, superficial, immersed when young, 180-200(-300) $\mu \mathrm{m}$ in diam., K/I reaction of sterile hyphae negative; disc black, flattened or \pm globose (Fig. 1a); epihymenium dark green or light brown; hymenium hyaline or \pm light brown, \pm light green towards hypothecium, 75-90 $\mu \mathrm{m}$ (Figs 1b, 1c); hypothecium dark brown to red brown, 65-90 $\mu \mathrm{m}$ high in water; asci 8-spored, clavate or ellipsoid, 55-65 × 17-14 $\mu \mathrm{m}$; ascospores 
2-celled, light blue-green, greenish brown or \pm brown in water, \pm verruculose, upper cell \pm broader, $12.25-14.7 \times 4.5-4.9 \mu \mathrm{m}$ (Figs 1c-d); pycnidia \pm immersed, outer wall $\mathrm{K} \pm$ green, I-; conidia hyaline, ellipsoid to obpyriform, 5.0-5.5 $\times$ $3.5-4.0 \mu \mathrm{m}$. A detailed description is provided by Kotte (1909).

Abrothallus peyritschii grows on the thallus and soredia of Vulpicida species and infection is \pm evident on these specimens.

Specimen examined: Turkey, Burdur province, between İbecik and Altınyayla villages, on main roadside, $36^{\circ} 58^{\prime} 07.19^{\prime \prime} \mathrm{N}$, $29^{\circ}$ $26^{\prime} 17.70^{\prime \prime}$ E, $1348 \mathrm{~m}$, on Vulpicida pinastri, leg.: Yazici, K., 29.06.2012 (KTUB-2450), det. Yazici, K.

Distribution: Abrothallus peyritschii is previously known throughout Europe (Austria, Belarus, Czech Republic, England, Estonia, Finland, France, Germany, Italy, Norway, Poland, Russia, Spain, Sweden, Switzerland); Asia (Russia: Altai-Sayan, China, India, Kyrgyzstan), Greenland, New Zealand and North America (Golubkov 2011, Obermayer 2004, Roux 2012, Sedelnikova 2013, Suija 2006, Wirth et al. 2011). This species is new to Turkey.

\section{Lichenochora verrucicola (Wedd.)}

Nik. Hoffm. et Hafellner, Bibl. Lichenol. 77: 55 (2000)

(Figs 2a-d)

Mycelium mostly inconspicuous and developing in one or several irregular galls containing perithecia and pycnidia on the thallus of Aspicilia cinerea (Fig. 2a). Perithecia black, \pm semi-immersed or immersed in the galls, $180-250 \mu \mathrm{m}$ diam., $250-350 \mu \mathrm{m}$
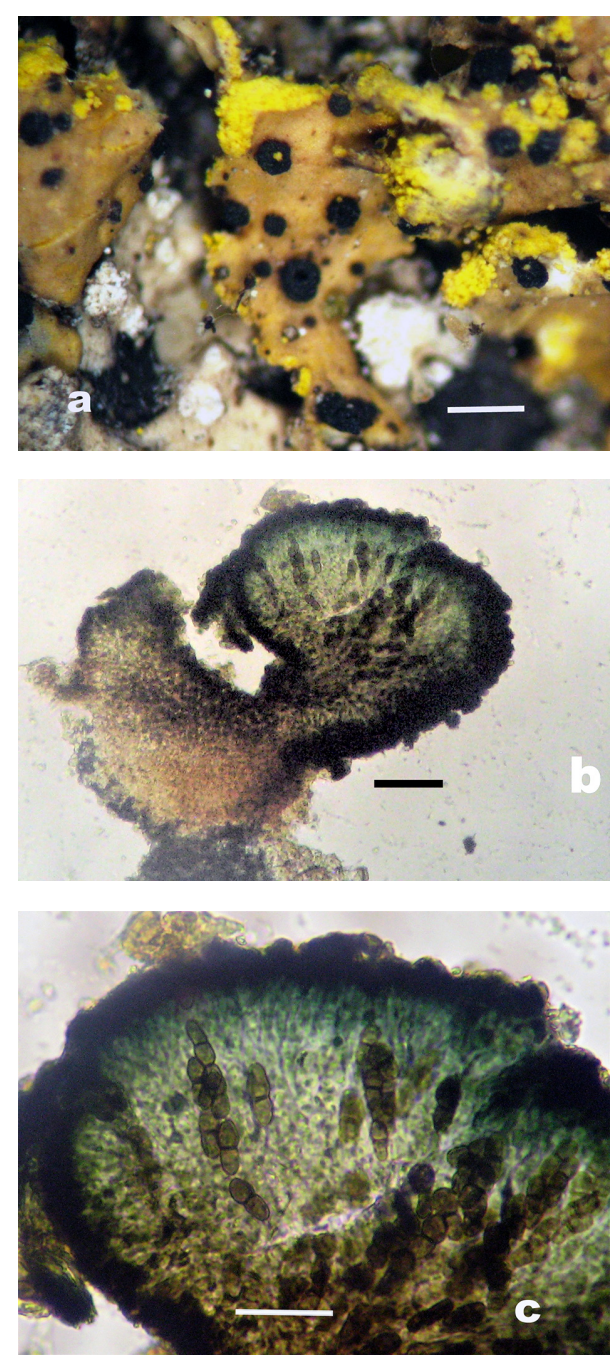

Fig. 1. Abrothallus peyritschii $-\mathrm{a}=$ ascomata on thallus of Vulpicida pinastri (scale: 500 $\mu \mathrm{m}) ; \mathrm{b}=$ section through an ascoma with ascospores, epihymenium, hymenium and hypothecium, in water (scale: $20 \mu \mathrm{m}$ ); $\mathrm{c}=$ section of ascoma with ascus and ascospores, epihymenium, hymenium and hypothecium, in water (scale: $20 \mu \mathrm{m}$ ) 
tall, with \pm dark brown wall; hymenium hyaline, with small or large droplets (Figs $2 \mathrm{~b}-\mathrm{c}$ ); paraphyses branched-anastomose; asci unitunicate, clavate, 4-8-spored, 80-90 × 16-20 $\mu \mathrm{m}$; ascospores simple, tellipsoid or mostly oblong, hyaline, $18.50-26.5 \times 6.5-8.35 \mu \mathrm{m}$ (Fig. $2 \mathrm{~d}$ ). Pycnidia present; conidia filiform, $20 \times 2 \mu \mathrm{m}$. A detailed description is provided by Hoffmann and Hafellner (2000) and Nash et al. (2001).

Lichenochora verrucicola mainly occurs on the thallus of Aspicilia cinerea, Circinaria contorta and other aspicilioid species (Nash et al. 2001, Navarro-Rosinés et al. 1998) with an evident pathogenic effect on the host.

Specimen examined: Turkey, Bitlis province, Adilcevaz district, south of Sodalı Lake, near Karşıyaka village, $38^{\circ} 49^{\prime} 26.29^{\prime \prime} \mathrm{N}, 42^{\circ} 57^{\prime} 16.60^{\prime \prime}$ E, $1712 \mathrm{~m}$, on Aspicilia cinerea, leg. Yazici, K., 17.07.2016 (KTUB-2455), det. Yazici, K. and Etayo, J.
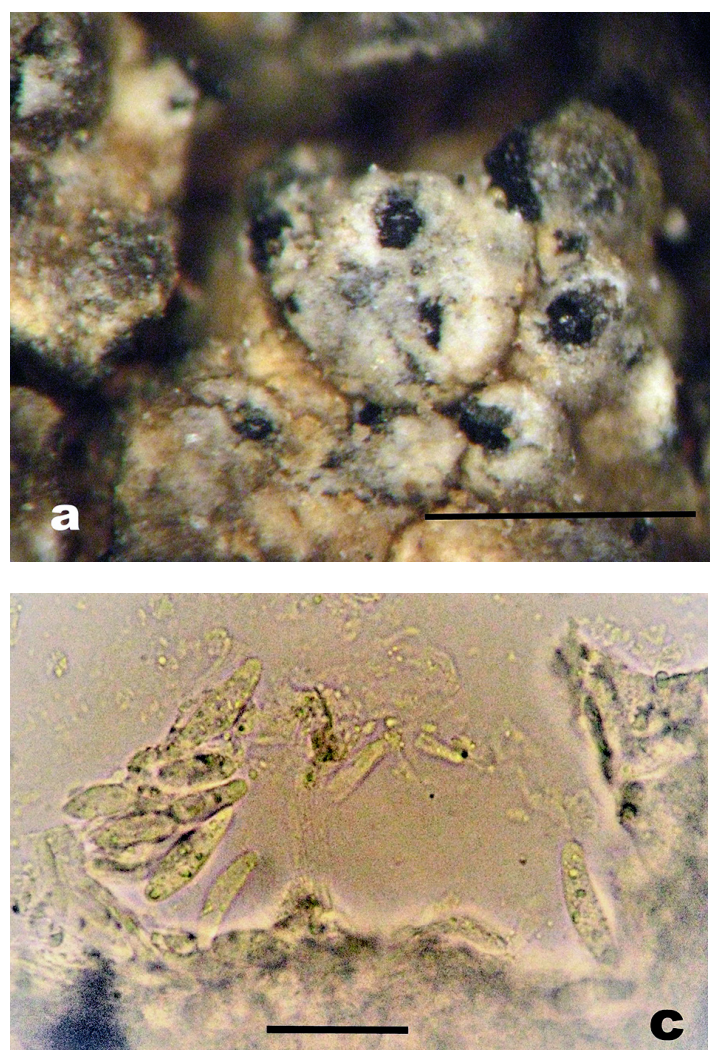
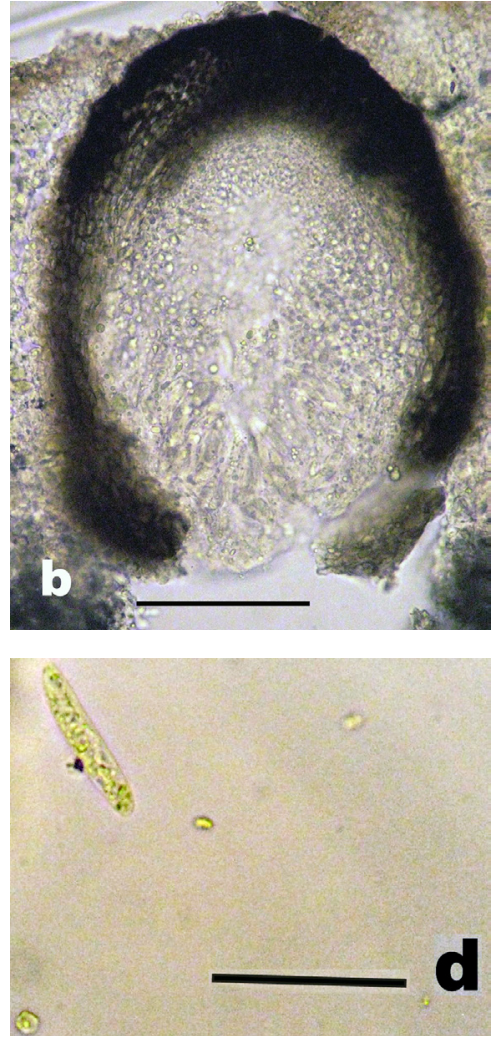

Fig. 2. Lichenochora verrucicola $-\mathrm{a}=$ ascomata on thallus of Aspicilia cinerea (scale: $1 \mathrm{~mm}$ ); $\mathrm{b}=$ section through the perithecium with large droplets, ascus and ascospores, in water (scale: $50 \mu \mathrm{m}) ; \mathrm{c}=$ section of perithecium with ascus, ascospores, in water (scale: $30 \mu \mathrm{m}$ ); $\mathrm{d}=$ ascospore, in water (scale: $30 \mu \mathrm{m}$ ) 
Distribution: This species is previously known from Europe (France, Spain, the Netherlands), India and North America (Joshi et al. 2016, Knudsen 2006, Sparrius et al. 2002). It is new to Turkey.

Remarks: Lichenochora verrucicola is similar to $L$. thorii as both species have simple ascospores but those in $L$. verrucicola are larger and finally becoming brown (Zhurbenko 2008).

\section{Sclerococcum montagnei Hafellner, Herzogia 12: 139 (1996)}

(Figs $3 a-d)$

Lichenicolous fungus with convex, rough surfaced, dark brown to black sporodochia of $350-450 \mu \mathrm{m}$ in diam. (Fig. 3a); conidiophores with brown cells mainly aggregated and \pm distinguishable among hyaline mycelia in K (Fig. 3b); conidia mainly 2-celled, rarely 1-celled brown (dark brown in K), tirregularly and \pm uneven thick wall, \pm constricted at the septa with thicker wall, 8.0-10.5 × 4.9-7.3 $\mu \mathrm{m}$, ellipsoid, \pm straight or somewhat curved, ends rounded or slightly pointed (Fig. 3c). A detailed description is provided by Hafellner (1996) and Nash et al. (2001).

Sclerococcum montagnei mainly occurs on the thallus areoles of $L e$ canora rupicola group (Coppins 1997, Etayo and Calatayud 1998, Hafellner 1996, Hawksworth et al. 2010, Nash et al. 2001), and grows mostly on the margin of areoles of L. rupicola.

Specimen examined: Turkey, Bitlis province, Güroymak district, near Günkırı village, $38^{\circ} 34^{\prime} 30.06^{\prime \prime} \mathrm{N}, 41^{\circ} 58^{\prime} 33.94^{\prime \prime} \mathrm{E}$,
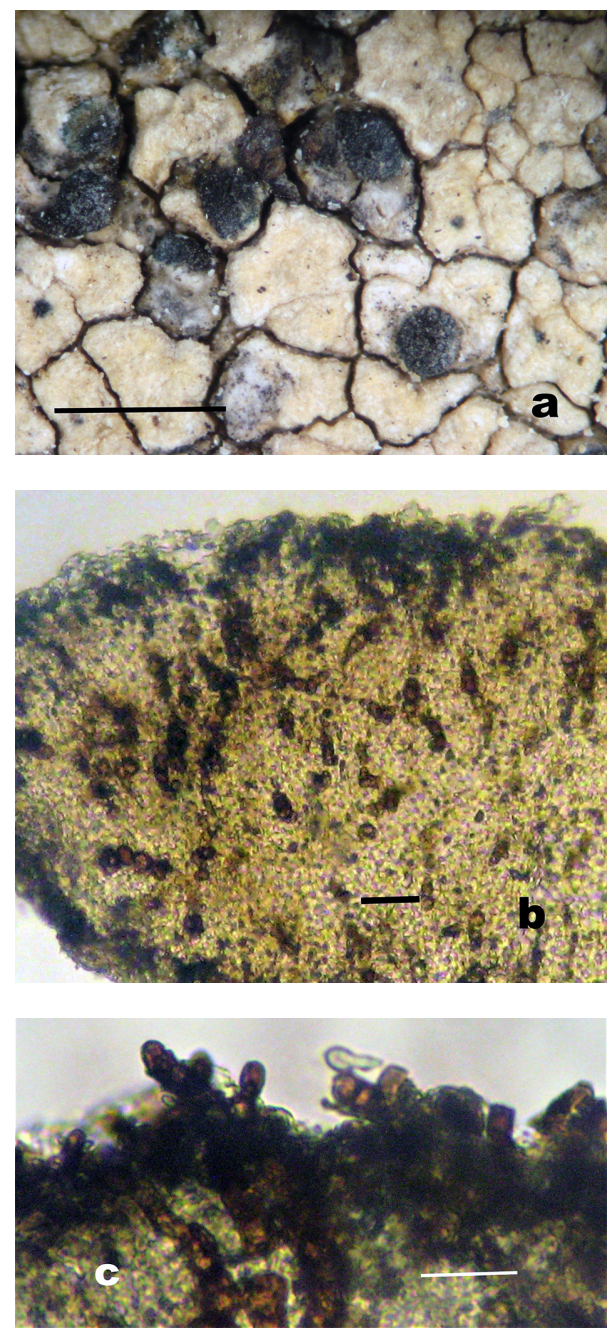

Fig. 3. Sclerococcum montagnei $-\mathrm{a}=$ sporodochia on thallus of Lecanora rupicola (scale: $1 \mathrm{~mm}) ; \mathrm{b}=$ hyaline mycelia and $1-$ and 2-celled conidia, in water (scale: $20 \mu \mathrm{m}$ ); c = hyaline mycelia, 1 - and 2-celled conidia, in $\mathrm{K}$ (scale: $20 \mu \mathrm{m}$ ) 
1511 m, on Lecanora rupicola, leg. Yazici, K., 06.08.2016 (KTUB-2453), det. Yazici, K., Aslan, A. and Etayo, J.

Distribution: Previously known from Europe (England, France, Germany, Ireland, Italy, the Netherlands, Scotland, Spain, Wales), Canary Islands and North America (Aptroot et al. 2004, Brackel 2008, Coppins 1997, Etayo and Calatayud 1998, Hafellner 1996, Hawksworth et al. 2010, Hutten et al. 2013, Wirth et al. 2011). This species is new to Turkey and Asia

Remarks: Sclerococcum montagnei resembles S. sphaerale but walls of conidia in S. montagnei are with fissures, irregular and uneven (Etayo and Calatayud 1998, Yazici and Etayo 2014).

Acknowledgements - We are grateful to Dr Javier Etayo for revisions and helpful comments on an earlier draft of this manuscript and also his comments about the identification of the species. This study was supported by TUBITAK (projects 111 T857 and 114Z892).

\section{REFERENCES}

Akman, Y. (1999): İklim ve Biyoiklim (Biyoiklim Metodları ve Türkiye İklimleri). 1. - Baskı, Kariyer Matbaacılık Ltd. Şti., Ankara, 350 pp.

Aptroot, A., Herk, C. M., Sparrius, L. B. and Spier, J. L. (2004): Checklist van de Nederlandse korstmossen en licheenparasieten. - Buxbaumiella 69: 16-55.

Brackel, W. von (2008): Zwackhiomyces echinulatus sp. nov. and other lichenicolous fungi from Sicily, Italy. - Herzogia 21: 181-198.

Brackel, W. von (2015a): Checklist of lichenicolous fungi in Germany, version 3: 2015. https://vonbrackel.de/pdf/Brackel 2015 Checklist Germany.pdf

Brackel, W. von (2015b): Preliminary checklist of the lichenicolous fungi of Italy, version 1: 2015. https://vonbrackel.de/pdf/Brackel 2015 Checklist Italy.pdf

Coppins, B. J. (1997): New, rare and interesting British lichen and lichenicolous fungus records. - Br. Lichen. Soc. Bull. 81: 32-37.

Czyżewska, K. and Kukwa, M. (2009): Lichenicolous fungi of Poland. A catalogue and key to species. - Biodiversity of Poland 11: 1-133.

Darmostuk, V. V. and Khodosovtsev, A. Ye. (2017): Lichenicolous fungi of Ukraine: an annotated checklist. - Studies in Fungi 2(1): 138-156. [in Ukrainian]. https://doi.org/10 $.5943 / \mathrm{sif} / 2 / 1 / 16$

Diederich, P. (2015): Two new lichenicolous species of Sclerococcum (asexual Ascomycetes) growing on Graphidaceae. - Bull. Soc. Nat. Luxemb. 117: 35-42.

Etayo, J. and Calatayud, V. (1998): Sclerococcum (Deuteromycotina) with black sporodochia in Spain. - Ann. Naturhist. Mus. Wien 10B: 677-681.

Golubkov, V. V. (2011): Annotated checklist of lichenicolous fungi of Belarus. - Botany, Research 40: 295-306. [in Russian]

Hafellner, J. (1996): Bemerkenswerte Funde von Flechten und lichenicolen Pilzen auf makaronesischen Inseln V. Über einige Neufunde und zwei neue Arten. - Herzogia 12: 133-145. 
Hawksworth, D. L. (2003): The lichenicolous fungi of Great Britain and Ireland: an overview and annotated checklist. - Lichenologist 35(3): 191-232. https://doi.org/10.1016 /s0024-2829(03)00027-6

Hawksworth, D. L., Atienza, V. and Coppins, B. J. (2010): Artificial keys to the lichenicolous fungi of Great Britain, Ireland, the Channel Islands, Iberian Peninsula, and Canary Islands. 4th draft ed. - The authors, mscr.

Hoffman, N. and Hafellner, J. (2000): Eine Revision der lichenicolen Arten der Sammelgattungen Guignardia und Physalospora (Ascomycotina). - Bibl. Lichenol. 77: 1-181.

Hutten, M., Arup, U., Breuss, O., Esslinger, T. L., Fryday, A. M., Knudsen, K., Lendemer, J. C., Printzen, C., Root, H. T., Schultz, M., Sheard, J., Tønsberg, T. and McCune, B. (2013): Lichens and lichenicolous fungi of Yosemite National Park, California. - North American Fungi 8(11): 1-47. https://doi.org/10.2509/naf2013.008.011

John, V. and Türk, A. (2017): Türkiye Likenleri Listesi. [A checklist of the lichens of Turkey.] - Nezahat Gökyiğit Botanik Bahçesi Yayım, İstanbul, 831 pp.

Joshi, Y., Falswal, A., Tripathi, M., Upadhyay, S., Bisht, A., Chandra, K., Bajpai, R. and Upreti, D. K. (2016): One hundred and five species of lichenicolous biota from India: an updated checklist for the country. - Mycosphere 7(3): 268-294. https://doi.org/10.5943 /mycosphere $/ 7 / 3 / 3$

Knudsen, K. (2006): Noteworthy collections: lichens and lichenicolous fungi. - Crossosoma 32: 31-33.

Kocakaya, M., Halıc1, M. G. and Pino Bodas, R. (2016): New or additional cladoniicolous fungi for Turkey. - Turkish J. Bot. 40: 308-311. https://doi.org/10.3906/bot-1502-8

Kocourková, J. (2009): Lichenicolous fungi of the Czech Republic (including lichenicolous $l i-$ chens). Version March 10, 2009. - http://www.nm.cz/download/pm/myko/list_of _lichen_fungi_cz.doc.

Kotte, I. (1909): Einige neue Fälle von Nebensymbiose (Parasymbiose). - Zentralbl. Bakteriol., Parasitenkd. II, 24: 74-93.

Lawrey, J. D. and Diederich, P. (2003): Lichenicolous fungi: interactions, evolution and biodiversity. - The Bryologist 106: 80-120. https://doi.org/10.1639/0007-2745(2003)106 [0080:lfieab]2.0.co;2

Lawrey, J. D. and Diederich, P. (2018): Lichenicolous fungi - worldwide checklist, including isolated cultures and sequences available. - http://www.lichenicolous.net (accessed 01.03.2018).

Lindsay, W. L. (1857): Monograph of the genus Abrothallus (De Notaris and Tulasne emend). - Quart. J. Microscop. Sci. 5: 27-63.

Nash, T. H., Ryan, B. D., Gries, C. and Bungartz, F. (eds) (2001): Lichen flora of the Greater Sonoran Desert Region. Vol. 2. - Arizona State University, Tempe, Arizona, 742 pp.

Navarro-Rosinés, P., Boqueras, M. and Roux, C. (1998): Nuevos datos para el género Lichenochora (Phyllachorales, Ascomicetes liquenícolas). - Bull. Soc. linn. Provence 49: 107-124.

Obermayer, W. (2004): Additions to the lichen flora of the Tibetan region. - Bibl. Lichenol. 88: 479-526.

Roux, C. (2012): Liste des lichens et champignons lichénicoles de France. - Bull. Soc. Linn. Provence, Num. spec. 16: 1-220.

Santesson, R., Moberg, R., Nordin, A., Tønsberg, T. and Vitikainen, O. (2004): Lichen-forming and lichenicolous fungi of Fennoscandia. - Museum of Evolution, Uppsala University, Uppsala, 359 pp. 
Sedelnikova, N. V. (2013): Species diversity of lichens biota of the Altai-Sayan ecological region. - Растительный мир Азиатской России 2(12c): 12-54.

Sparrius, L. B., Aptroot, A., van Herk, C. M. and Brand, A. M. (2002): Nieuwe en interessante korstmossen en korstmos-parasieten in Nederland met aanvullingen en wijzigin-gen op de checklist. - Buxbaumiella 59: 26-46.

Suija, A. (2006): Variation of morphological characters in the lichenicolous ascomycete genus Abrothallus. - Ann. Bot. Fennici 43: 193-204.

Suija, A., de los Ríos, A. and Pérez-Ortega, S. (2015): A molecular reappraisal of Abrothallus species growing on lichens of the order Peltigerales. - Phytotaxa 195: 201-226. https://doi.org/10.11646/phytotaxa.195.3.1

Wirth, V., Hauck, M., von Brackel, W., Cezanne, R., de Bruyn, U., Dürhammer, O., Eichler, M., Gnüchtel, A., Litterski, B., Otte, V., Schiefelbein, U., Scholz, P., Schultz, M., Stordeur, R., Feuerer, T., Heinrich, D. and John, V. (2011): Checklist of lichens and lichenicolous fungi in Germany. Version \#2: 19 January 2011. - Georg August University of Göttingen: http://www.gwdg.de/ mhauck, Göttingen, Germany.

Yazici, K. and Etayo, J. (2014): Lichenicolous fungi in Iğdır province, Turkey. - Acta Bot. Brasilica 28(1): 1-7. https://doi.org/10.1590/s0102-33062014000100001

Yazici, K., Etayo, J. and Aslan, A. (2011): A note about lichenicolous fungi from Ardahan (Turkey). - Cryptogamie, Mycol. 32: 429-437. https://doi.org/10.7872/crym.v32.iss4 .2011 .429

Zhurbenko, M. (2008): Lichenochora thorii (Phyllachorales), a new lichenicolous ascomycete from Europe. - Nova Hedwigia 87(3-4): 509-512. https://doi.org/10.1127/0029 $-5035 / 2008 / 0087-0509$ 